Original Contribution

\title{
BLOOD PARAMETERS, CARCASS YIELD, ORGAN WEIGHT AND VILLI MORPHOMETRICS OF BROILERS FED LOW PROTEIN DIET IN EXCESS OF DIETARY LYSINE
}

\author{
T. K. Ojediran*, T. O. Oloruntade, B. Y. Durojaye, R. O. Saka, I. A. Emiola
}

Department of Animal Nutrition and Biotechnology, Ladoke Akintola University of Technology, Ogbomoso, Nigeria.

\begin{abstract}
One hundred and fifty day-old Abor-acre strain broilers chicks were used to evaluate the blood parameters, carcass yield, organ weight and villi morphometrics of broilers fed low protein diet in excess of dietary lysine. The chicks were weighed on the eight day and then randomly assigned to five experimental diets in such a way that each dietary treatment had 30 birds replicated thrice. Diet 1 was the control with $22.22 \%$ crude protein (CP) while diets $2,3,4$ and 5 contained $16.6 \%$ CP each at both starter and finisher phases with varying levels of lysine ranging from 0.50 to $0.90 \%$. They all had the same level of methionine. Results showed that the birds fed diet 4 (16.6\% CP and $0.8 \%$ lysine inclusion level) had a significantly $(\mathrm{p}<0.05)$ higher breast, villi height, crypt depth and muscle thickness while the lymphocyte count, total protein, abdominal fat and back size increased linearly with lysine inclusion unlike decreases in heterophil among birds fed LCP diets. It can be concluded that increased villi morphology enhanced breast yield due to enhanced absorption with increased abdominal fat as observed in birds fed $16.6 \% \mathrm{CP}$ and $0.8 \%$ lysine inclusion level.
\end{abstract}

Key words: amino acid, haematology, jejunum, meat, organ, serum

\section{INTRODUCTION}

The advent of commercial available synthetic amino acids has made it possible to decrease crude protein to a degree, but has also furthered the need for the assessment of the limiting amino acids in low protein diets. Amino acids have been known to play an important role in animal performance. (1) reported that animals with good blood composition are likely to show good performance. According to (2) and (3), the examination of blood gives the opportunity to investigate the presence of several metabolites and other constituents in the body of animals which (4) stated could serve as baseline information for comparison as it plays a vital role in the physiological, nutritional and pathological status of an organism while (5) buttress the fact that haematological parameters are good indicators of the physiological status of animals. Meanwhile, serum parameters indicate the status and

\footnotetext{
*Correspondence to: $T$. K. Ojediran, Department of Animal Nutrition and Biotechnology, Ladoke Akintola University of Technology, P. M. B. 4000, Ogbomoso, Nigeria, ojedirantaiwo@gmail.com or tkojediran@lautech.edu.ng +234-8034104295
}

integrity of vital organs in the body which (6) observed to contribute to the viscosity and maintenance of normal blood pressure and $\mathrm{pH}$.

Carcass yield and quality is important in the poultry industry, due to increasing consumer interest in lean meat and low cholesterol diet (7) which (8) noted that can be influenced by the crude protein and amino acid status of a diet. Although, (9) had earlier stated that different nutritional component, protein and the amino acid type in the diet are fundamentals, because they are related with synthesis of structural tissues. (10) reported that diets formulated with high lysine level thus promoted a better conversion of the diet into efficient carcass. The concentration of dietary lysine significantly influenced breast meat according to (11) because the breast meat contains a high concentration of lysine and it represent a large portion of carcass meat, (12) observed an increase in thigh weight with increasing lysine in a low crude protein diet contrary to the observation of (13) that increasing lysine concentration in broiler diets from 21 to 42 days of age did not affect breast meat and thigh meat, but significantly decrease excess abdominal fat. 
A protein deficiency, caused by either one or more limiting amino acids or an overall inadequate consumption of protein, resulted in decreases in parameters such as nitrogen retention and feed utilization (14), while an over-consumption of protein according to (15) results in the catabolism of amino acids through deamination and excretion as uric acid which is both energetically and economically inefficient, or in severe cases, ammonia toxicity (16). It is essential to try to meet the requirement of the bird as closely as possible in order to maximize production and profitability.

Thus, combining available feed ingredients in the best possible way becomes paramount because feeding birds with poor quality feed due to high cost of feeding will result in physiological imbalance and yield poor carcass (17).

\section{MATERIALS AND METHOD}

\section{Experimental site, feedstuffs and duration}

The experiment was carried at the Teaching and Research Farm of the Ladoke Akintola University of Technology, Ogbomoso, Nigeria located in the derived savannah zone on latitude $18^{\circ} 15^{\prime}$ north of the equator and longitude $4^{\circ} 5^{\prime}$ east of the Greenwich meridian (18). Maize and cassava pulp flour were the major energy sources while soybean was the major protein source. The experiment lasted for six weeks.

\section{Experimental Birds}

One hundred and fifty day old broilers of Abor-acre strain bought from a reputable farm at Ibadan were used for this feeding trial. The broilers were fed on conventional feed during the first week to allow for acclimatization on a deep litter. The chicks were weighed on the eight day and then randomly assigned to the experimental diets (Table 1) in such a way that each dietary treatment had 30 birds replicated thrice. The experimental feed and water were supplied ad libitum. Routine vaccination and necessary medications were administered. Records of feed intake were taken daily, body weight gain on weekly basis and mortality records were also taken. At the last week of the experiment an indigestible marker, Titanium dioxide $\left(\mathrm{TiO}_{2}\right)$ was included in the diets to monitor digestibility of the feed.

Table 1. Gross composition of experimental diet

\begin{tabular}{llllll}
\hline Ingredients (\%) & $\mathrm{T}_{1}($ Control) & $\mathrm{T}_{2}$ & $\mathrm{~T}_{3}$ & $\mathrm{~T}_{4}$ & $\mathrm{~T}_{5}$ \\
\hline Maize & 54.20 & 54.10 & 54.00 & 53.90 & 53.80 \\
Soybean meal & 40.00 & 26.00 & 26.00 & 26.00 & 26.00 \\
Cassava meal & 0.00 & 14.00 & 14.00 & 14.00 & 14.00 \\
Lysine & 0.50 & 0.60 & 0.70 & 0.80 & 0.90 \\
*Fixed ingredients & 5.30 & 5.30 & 5.30 & 5.30 & 5.30 \\
Total & 100.00 & 100.00 & 100.00 & 100.00 & 100.00 \\
\hline Calculated Nutrient Composition & & & & \\
Crude Protein (\%) & 22.22 & 16.68 & 16.67 & 16.66 & 16.65 \\
ME (Kcal/kg) & 2941.23 & 3047.79 & 3044.36 & 3000.93 & 2997.49 \\
Lysine (\%) & 1.73 & 1.44 & 1.53 & 1.63 & 1.72 \\
Methionine (\%) & 0.58 & 0.50 & 0.50 & 0.50 & 0.50 \\
\hline
\end{tabular}

*Fixed ingredients are Titanium dioxide, Dicalcium phosphate, Limestone, Salt, ${ }^{\#}$ Broiler Premix and Methionine. ME-metabolizable energy

\#2.5 kg Premix used supplied vitamin A, 12,500000iv: vitamin D, 2500000iv; vitamin E,40,000mg; vitamin K3,2000mg;vitamin B1, 3000mg; vitamin B2 5500mg Niacin, 55000mg;calcium pantothenate, 11500mg vitamin B6, 5000mg; vitamin B12, 25mg; Folic acid,1000mg;biotin,80mg;choline chloride 500000mg;manganese, 120000mg; Iron100,000mg;zinc,80000mg;copper 8500mg;iodine 1500mg cobalt 3000mg;selenium 120mg and anti-oxidant 120,000mg.

\section{Data Collection}

\section{Blood Chemistry Analysis}

Three birds per treatment were randomly selected and slaughtered by cutting the jugular vein. $5 \mathrm{ml}$ of blood was collected into two sets of three sterilized glass bottles/tubes. For haematology, blood samples were collected into two sets of three sterilized bottles containing Ethylene Diamine Tetra-acetic Acid (EDTA). Blood samples for serum biochemical studies were collected into plain bottles (i.e without anticoagulant) for serum seperation. Serum was obtained by centrifugation and serum samples were stored in a deep freezer (at minus $10^{\circ} \mathrm{C}$ ) until required for analysis.

Blood parameters such as packed cell volume (PCV) and haemoglobin ( $\mathrm{Hb})$ were determined using the micro haematocrit method and cyanmethehemoglobin methods respectively as described by (19). Erythrocyte count (RBC) and Leukocyte count (WBC) were determined using the improved Neubauer haemocytometer 
after the appropriate dilution (20). Differential leukocyte counts were determined by scanning Giemsa's stained slides in the classic manner (20).

Mean corpuscular haemoglobin $(\mathrm{MCH})$ was calculated as haemoglobin/RBC x 10, and Mean corpuscular volume (MCV) was also calculated by Haematocrit/RBC x 10 while Mean corpuscular haemoglobin concentration (MCHC) was estimated by Haemoglobin/Haematocrit x 100.

Total cholesterol, triglycerides and high density lipoproteins (HDL) was assayed using the method of (21). Very low density lipoproteins (VLDL) were estimated (triglycerides/5) (22) while low density lipoproteins (LDL) was estimated using the Friedewald equation (LDL=Total cholesterol-(HDL-tryglycerides/5) Alanine Transaminase (ALT), Aspartate amino Transaminase (AST) and Alanine phosphatase (ALP) was determined manually by spectrophotometric method respectively as described by (23). Total serum protein was determined using the biuret method while albumin was determined using the BCG (Bromocresol green) method as described by (24) with globuline concentration obtained by subtracting albumin from the total protein.

\section{Organs and Carcass Evaluation}

At the end of the experimental period, 3 birds per treatment were selected randomly and weighed. After 6 hours of feed withdrawal, the birds were slaughtered by cutting off the jugular vein and allowed to bleed completely. Visceral organs (liver, kidney, pancreas, gizzard, spleen, heart, and lungs were eviscerated before scalding and defeathering) and carcass cuts (wing, thigh, drum stick, breast, and shank) were weighed using a
OJEDIRAN T. K., et al. sensitive weighing balance and expressed as percentage of live weight.

\section{Villi morphometrics}

Jejunum samples from the intestine of slaughtered birds were preserved in $10 \%$ formalin on replicate basis in vacuum bottles before being taken to the laboratory for the micrographic evaluation.

\section{Statistics}

The experiments employed a complete randomized design, all data generated were subjected to analysis of variance in case of significance the means were separated with Duncan multiple range test using SAS package (25).

\section{RESULTS \\ Blood parameters}

Effect of low crude protein supplemented with varying lysine inclusion level on haematological parameters of broilers chicken is shown in Table 2. The Packed cell volume (PCV), Haemoglobin $(\mathrm{Hb})$, Red blood cell (RBC), White blood cell (WBC), Monocytes, Eosinophil, Basophil, Platelet, Mean corpuscular volume (MCV), Mean corpuscular haemoglobin (MCH) and Mean corpuscular haemoglobin concentration $(\mathrm{MCHC})$ were not significantly affected $(\mathrm{P}>0.05)$ by the dietary treatment, while the lymphocyte and heterophil count significantly varied significant $(\mathrm{p}<0.05)$ with lymphocyte counts increasing while the heterophil count decreased linearly with lysine inclusion among the diets from those fed the control diet to those fed LCP diets. The lymphocyte counts was lowest for the control $\left(54.67 \times 10^{6} \mathrm{ul}\right)$ and highest at bird fed T5 $\left(71.67 \times 10^{6} \mathrm{ul}\right)$ while those fed T2-T4 were comparable while T1 $\left(37.67 \times 10^{6} \mathrm{ul}\right)$ had the highest value and T5 $\left(21.00 \times 10^{6} \mathrm{ul}\right)$ had the least for heterophil count.

Table 2. Haematological parameters of broilers fed low crude protein diets supplemented with varying levels of lysine

\begin{tabular}{lllllll}
\hline Parameter & $\mathrm{T}_{1}$ & $\mathrm{~T}_{2}$ & $\mathrm{~T}_{3}$ & $\mathrm{~T}_{4}$ & $\mathrm{~T}_{5}$ & SEM \\
\hline PCV $(\%)$ & 30 & 31.3 & 27.3 & 30 & 30.3 & 0.62 \\
Haemoglobin $(\mathrm{g} / \mathrm{dl})$ & 9.50 & 10 & 8.8 & 9.5 & 10 & 0.24 \\
RBC $\left(10^{6} \mathrm{ul}\right)$ & 3.55 & 3.52 & 2.83 & 3.40 & 3.28 & 3.12 \\
WBC $\left(10^{3} \mathrm{ul}\right)$ & 24.7 & 20.4 & 20.5 & 24.8 & 20.2 & 1.37 \\
Lymphocyte $\left(\times 10^{6} \mathrm{ul}\right)$ & $54.7^{\mathrm{b}}$ & $60.3^{\mathrm{ab}}$ & $64.7^{\mathrm{ab}}$ & $65^{\mathrm{ab}}$ & $71.7^{\mathrm{a}}$ & 2.12 \\
Heterophil $\left(\mathrm{x} 10^{6} \mathrm{ul}\right)$ & $37.7^{\mathrm{a}}$ & $33^{\mathrm{a}}$ & $28.3^{\mathrm{ab}}$ & $27.7^{\mathrm{ab}}$ & $21^{\mathrm{b}}$ & 1.98 \\
Monocytes $\left(\times 10^{6} \mathrm{ul}\right)$ & 3.33 & 3 & 3.33 & 2.33 & 3 & 0.34 \\
Eosinphils $\times\left(10^{6} \mathrm{ul}\right)$ & 3.67 & 3.33 & 3.67 & 4.67 & 3.67 & 0.35 \\
Basophils $\times\left(10^{6} \mathrm{ul}\right)$ & 0.67 & 0.33 & 0 & 0.33 & 0.67 & 0.13 \\
Platelet $\times\left(10^{4} \mathrm{ul}\right)$ & 29.5 & 21 & 21.5 & 29.5 & 22.3 & 22.3 \\
MCV $(\mathrm{Fl})$ & 84.8 & 88.9 & 103 & 88.2 & 92.7 & 84.1 \\
MCH (Pg) & 26.9 & 28.5 & 33.2 & 27.9 & 30.6 & 1.19 \\
MCHC $(\%)$ & 0.32 & 0.32 & 0.32 & 0.32 & 0.33 & 0.003 \\
\hline
\end{tabular}

${ }^{\mathrm{a}, \mathrm{b}}$ means the superscript differs significantly at $(\mathrm{p}<0.05)$ within the same row

SEM; standard error of mean, $\mathrm{PCV}=$ Packed Cell Volume, $\mathrm{RBC}=$ Red Blood Cell, WBC $=$ White Blood Cell, $\mathrm{MCV}=$ Mean corpuscular volume, $\mathrm{MCH}=$ Mean corpuscular haemoglobin, $\mathrm{MCHC}=$ Mean corpuscular haemoglobin concentration 
Table 3 shows the serum parameters of broiler chickens fed with low crude protein supplemented with varying levels of lysine. The total protein and globulin, were significantly $(\mathrm{p}<0.05)$ influenced by the dietary treatment. Total Protein followed the same trend as Globulin with birds on $\mathrm{T}_{4}$ having a
OJEDIRAN T. K., et al. higher $(\mathrm{p}<0.05)$ value from those fed other treatments. Triglyceride, Cholesterol, Albumin, Uric Acid, Urea, Very Low Density Lipoprotein (VLDL), Low Density Lipoprotein (LDL) and High Density Lipoprotein (HDL) were not significantly influenced $(p>0.05)$ by the dietary treatments.

Table 3. Serum biochemistry of broilers fed of low crude protein supplemented with varying levels of lysine

\begin{tabular}{lllllll}
\hline Parameter & $\mathrm{T}_{1}$ & $\mathrm{~T}_{2}$ & $\mathrm{~T}_{3}$ & $\mathrm{~T}_{4}$ & $\mathrm{~T}_{5}$ & SEM \\
\hline Triglyceride $(\mathrm{mg} / \mathrm{dl})$ & 50.4 & 58.3 & 80.4 & 54.8 & 54.8 & 4.91 \\
Cholesterol $(\mathrm{mg} / \mathrm{dl})$ & 74.2 & 73.2 & 94.8 & 103 & 79.3 & 5.68 \\
Total Protein( $\mathrm{g} / \mathrm{dl})$ & $2.47^{\mathrm{b}}$ & $2.63^{\mathrm{b}}$ & $2.63^{\mathrm{b}}$ & $3.83^{\mathrm{a}}$ & $2.61^{\mathrm{b}}$ & 0.17 \\
Albumin $(\mathrm{g} / \mathrm{dl})$ & 1.44 & 1.35 & 1.58 & 1.37 & 1.83 & 0.09 \\
Globulin $(\mathrm{mg} / \mathrm{dl})$ & $1.03^{\mathrm{b}}$ & $1.28^{\mathrm{b}}$ & $1.05^{\mathrm{b}}$ & $2.45^{\mathrm{a}}$ & $0.78^{\mathrm{b}}$ & 0.19 \\
Uric Acid $(\mathrm{mg} / \mathrm{dl})$ & 8.89 & 20 & 10.1 & 28.9 & 25.6 & 3.37 \\
Urea $(\mathrm{mg} / \mathrm{dl})$ & 0 & 0.74 & 0 & 1.28 & 1.11 & 0.34 \\
VLDL $(\mathrm{mg} / \mathrm{dl})$ & 10.1 & 11.7 & 16.1 & 11 & 11 & 0.98 \\
HDL $(\mathrm{mg} / \mathrm{dl})$ & 67.1 & 87 & 92.7 & 92.4 & 70.3 & 4.73 \\
LDL mg/dl & 17.1 & 2.14 & 18.2 & 21.3 & 20 & 4.38 \\
\hline
\end{tabular}

${ }^{a, b}$ means the superscript differs significantly at $(\mathrm{p}<0.05)$ within the same row

SEM=standard error of mean, ADG= Average Daily Gain, ADFI=Average Daily Feed Intake, VLDL=Very Low Density Lipoprotein, HDL=High density lipoprotein, LDL=Low Density Lipoprotein

\section{Organs weight}

The relative weights of the organs and abdominal fat were expressed as percentage of their live weights is as shown in Table 4. There were no significant differences $(\mathrm{P}>0.05)$ in the weights of the liver, kidney, lungs, whole gizzard, empty gizzard, pancreas, proventriculus, spleen and gastrointestinal tract (GIT) except for the heart and abdominal fat $(\mathrm{P}<0.05)$ with no definite pattern.

Table 4. Relative values of organs of broilers fed low crude protein diet supplemented with varying levels of lysine

\begin{tabular}{lllllllll}
\hline Parameters $(\%)$ & $\mathrm{T}_{1}$ & $\mathrm{~T}_{2}$ & $\mathrm{~T}_{3}$ & $\mathrm{~T}_{4}$ & $\mathrm{~T}_{5}$ & P.value & SEM & $\mathrm{R}^{2}$ value \\
\hline Liver & 2.50 & 2.63 & 2.27 & 2.30 & 2.28 & 0.90 & 8.12 & 0.09 \\
Kidney & 0.44 & 0.45 & 0.35 & 0.52 & 0.46 & 0.53 & 0.03 & 0.25 \\
Lungs & 0.49 & 0.56 & 0.52 & 0.40 & 0.55 & 0.64 & 0.03 & 0.25 \\
Heart & $0.53^{\mathrm{a}}$ & $0.43^{\mathrm{b}}$ & $0.37^{\mathrm{b}}$ & $0.56^{\mathrm{a}}$ & $0.41^{\mathrm{b}}$ & 0.01 & 0.02 & 0.74 \\
Whole gizzard & 2.40 & 2.74 & 2.60 & 2.40 & 2.40 & 0.48 & 0.07 & 0.27 \\
Empty gizzard & 1.57 & 1.64 & 1.66 & 1.48 & 1.57 & 0.72 & 0.04 & 0.17 \\
Pancreas & 0.28 & 0.25 & 0.21 & 0.24 & 0.23 & 0.86 & 0.02 & 0.11 \\
Proventriculus & 0.40 & 0.39 & 0.32 & 0.37 & 0.41 & 0.51 & 0.02 & 0.26 \\
Spleen & 0.13 & 0.12 & 0.11 & 0.10 & 0.09 & 0.56 & 0.01 & 0.24 \\
Abdominal Fat & $1.02^{\mathrm{b}}$ & $1.93^{\mathrm{ab}}$ & $2.42^{\mathrm{a}}$ & $2.30^{\mathrm{a}}$ & $1.78^{\mathrm{ab}}$ & 0.08 & 0.18 & 0.53 \\
GIT & 13.9 & 16.2 & 15.1 & 14.6 & 15.0 & 0.58 & 0.41 & 0.23 \\
\hline
\end{tabular}

${ }^{\mathrm{a}, \mathrm{b}}$ means the superscript differs significantly at $(\mathrm{p}<0.05)$ within the same row

SEM; standard error of mean, ADG= Average Daily Gain, ADFI=Average Daily Feed Intake, GIT:

Gastrointestinal Tract

\section{Carcass yield}

Carcass yield of broiler chickens fed low protein diets supplemented with lysine is presented in Table 5. The dietary treatments had no significant $(\mathrm{P}>0.05)$ effect on drumstick, thigh, wings, neck and shank, while the breast and back were significantly influenced $(\mathrm{P}<0.05)$. The breast was increasing as the lysine inclusion increases but reached a plateau at T4 while that of the back kept increasing. 
OJEDIRAN T. K., et al.

Table 5. Carcass yield of broiler finishers fed low crude protein diets supplemented with lysine

\begin{tabular}{lllllllll}
\hline Parameters $\%$ & $\mathrm{~T}_{1}$ & $\mathrm{~T}_{2}$ & $\mathrm{~T}_{3}$ & $\mathrm{~T}_{4}$ & $\mathrm{~T}_{5}$ & P.value & SEM & $\mathrm{R}^{2}$ value \\
\hline Drumstick & 10.8 & 10.7 & 10.1 & 9.35 & 9.34 & 0.17 & 0.25 & 0.45 \\
Thigh & 11.4 & 10.6 & 11.7 & 10.5 & 10.7 & 0.16 & 0.18 & 0.46 \\
Wings & 9.13 & 8.21 & 9.24 & 8.93 & 9.58 & 0.44 & 0.23 & 0.29 \\
Breast & $23^{\mathrm{ab}}$ & $16.5^{\mathrm{b}}$ & $19.9^{\mathrm{ab}}$ & $25.2^{\mathrm{a}}$ & $20.6^{\mathrm{ab}}$ & 0.09 & 1.08 & 0.52 \\
Neck & 5.41 & 5.19 & 5.76 & 5.03 & 5.27 & 0.45 & 0.12 & 0.28 \\
Back & $11.3^{\mathrm{b}}$ & $11.3^{\mathrm{b}}$ & $12.0^{\mathrm{ab}}$ & $12.1^{\mathrm{ab}}$ & $13.2^{\mathrm{a}}$ & 0.16 & 0.28 & 0.46 \\
Shank & 4.10 & 4.47 & 4.04 & 3.78 & 3.83 & 0.70 & 0.16 & 0.18 \\
\hline
\end{tabular}

${ }^{\mathrm{a}-\mathrm{b}}$ : along the same row with different superscript are significantly different $(\mathrm{P}<0.05)$

\section{Villi morphometrics}

Table 6 shows that lysine supplementation of LCP diets had significant effect $(\mathrm{P}<0.05)$ on villi height, villi width, cryptal depth and muscle thickness. Birds fed T4 had higher values for the observed jejunum characteristics except for villi width which was highest at T5 (148.08) The villi height of the broiler fed T4 (1167.87) was from those fed treatments 1,2, 3 and 5 which had 561.61, 758.53, 614.37 and 659.75 respectively. The villi width of birds fed T5 (148.04) had a higher value compared to those fed other treatments and notably as the lysine supplementation increases within the LCP diets the villi width increases. For the cryptal depth, birds on T4 had a higher value than the others and this is similar to what was observed for the muscle thickness.

Table 6. Small intestine characteristics (Villi morphometric) of broilers fed low crude protein diet

\begin{tabular}{lllllll}
\hline Parameters & $\mathrm{T}_{1}$ & $\mathrm{~T}_{2}$ & $\mathrm{~T}_{3}$ & $\mathrm{~T}_{4}$ & $\mathrm{~T}_{5}$ & SEM \\
\hline Villi height $(\mu \mathrm{m})$ & $562^{\mathrm{b}}$ & $759^{\mathrm{b}}$ & $614^{\mathrm{b}}$ & $1168^{\mathrm{a}}$ & $660^{\mathrm{b}}$ & 64.8 \\
Villi width $(\mu \mathrm{m})$ & $126.7^{\mathrm{ab}}$ & $104^{\mathrm{b}}$ & $107^{\mathrm{b}}$ & $116^{\mathrm{ab}}$ & $148^{\mathrm{a}}$ & 6.27 \\
Cryptal depth $(\mu \mathrm{m})$ & $230^{\mathrm{bc}}$ & $153^{\mathrm{c}}$ & $392^{\mathrm{b}}$ & $598^{\mathrm{a}}$ & $177^{\mathrm{c}}$ & 50.7 \\
Muscle Thickness $(\mu \mathrm{m})$ & $71.5^{\mathrm{ab}}$ & $86.0^{\mathrm{ab}}$ & $68.3^{\mathrm{ab}}$ & $92.3^{\mathrm{a}}$ & $62.5^{\mathrm{b}}$ & 4.23 \\
\hline
\end{tabular}

${ }^{a-b}$ : along the same row with different superscript are significantly different $(\mathrm{P}<0.05)$

SEM: Standard Error of Mean

\section{DISCUSSION}

\section{Blood parameters}

Blood parameters comprises of the hematological parameters as well as the serum biochemistry of the birds. The serum biochemistry is routinely used for detection of organ diseases in domestic mammals (26). It has been reported that serum biochemical constituents positively correlate with the quality of the diet (27). The non significant difference observed in most blood parameters agrees with the report of (28) and (13) which stated that lysine supplementation in feed of poultry had no effect on hematological parameters. However, hematological parameters obtained from this study suggest that dietary lysine supplementation has no deleterious effect on some physiological parameters of broiler chicken since hematological parameters fell within the normal range as reported by $(29-30)$. The significant response in Total protein and Globulin observed in this study are within the normal physiological values of chicken (31). Evelated total protein and globulin in birds fed T4 could indicate improved AA economy (32). The lower and non-significant cholesterol levels observed in this study are an indicator of health benefit of incorporating lysine to broiler chicken diets.

\section{Organs Weight}

The weight of organs in broilers according to (33) reflects the anatomical response of birds to the type of diet consumed. The percentage organs weight (liver, kidney, lungs, gizzard, pancreas, Proventriculus, spleen and GIT) were not significantly different $(\mathrm{P}>0.05)$. The non significant weight observed in most of the internal organs measured in this study in response to feeding low crude protein diet supplemented with varying level of lysine to broilers is an indication that such levels are tolerable by the broiler chicks. Liver, kidney, spleen, lungs, gizzard, pancreas, proventriculus and GIT weights were generally similar $(\mathrm{P}>0.05)$ for treated and control groups or higher for treatment groups compared to control showing that low crude protein diet supplemented with lysine was not detrimental to the birds. This was in agreement with (34), who reported that dressing percentage, liver, heart, spleen, gizzard, small and large intestine weights were generally similar for treated and control groups or higher for test groups compared to control showing that Gongronema latifolium inclusion in the diets was not detrimental to the birds.

The weight of the fat of broilers in the test groups (treatments 2, 3,4 and 5) had higher 
values and were significantly different from the control group. The observed result was in agreement with (35) who stated that decreasing dietary protein increased abdominal fat significantly $(\mathrm{P}<0.05)$. The significantly lower heart weight in groups fed treatments 2, 3 and 5 may be as a result of reduced cardiac activities. This result contradicts that of (34), who observed that, there was significantly larger heart associated with test birds that resulted from the inclusion of $G$. latifoliumin the diets.

\section{Small Intestine}

The villi height, villi width, cryptal depth and muscle thickness of the jejunum were significantly affected by the dietary treatment. This was in consonance with the findings of (36), who reported that villi height and width along with the number of crypts per the microscopic field of broilers fed organic acids or antibiotic growth promoter were differed between the control and the treated group.

\section{CONCLUSION}

It can be concluded from the results observed that birds fed $16.6 \% \mathrm{CP}$ and $0.8 \%$ lysine inclusion level had improved feed quality, increased abdominal fat, increased villi morphology and enhanced breast yield due to enhanced absorption.

\section{REFERENCES}

1. Isaac, L. J., Abah, G., Akpan, B. and Ekaette, I. U., Haematological properties of different breeds and sexes of rabbits. Proceedings of the 18th Annual Conference of Animal Science Association of Nigeria. Pp.24-27, 2013.

2. Aderemi, F. A., Effects of replacement of wheat bran with cassava root sieviate supplemented or unsupplemented with enzyme on the haematology and serum biochemistry of pullet chicks. Tropical Journal of Animal Science. 7: 147153.2004.

3. Doyle, D., William Hewson (1739-74). The father of haematology. British Journal of Haematology, 133(4), 375-381, 2006.

4. Daramola, J. O., Adeloye, A. A., Fatoba, T. A. and Soladoye, A. O., Haematological and biochemical parameters of West African Dwarf goats. Livestock Research for Rural Development, 17(8): 95, 2005.

5. Khan, T. A. and Zafar, F., Haematological Study in Response to Varying Doses of Estrogen in Broiler Chicken. International Journal of Poultry Science, 4(10): 748-751, 2005.

6. Ladokun, A. O., Yakubu, A., Otite, J. R., Omeje, J. N., Sokunbi, O. A. and Onyeji,
OJEDIRAN T. K., et al. E., Haematological and Serum biochemical indices of Naked and Nomally feathered Nigerian Indigeneous Chicken in the SubHumid Tropical Environment. Intl J. of Poult. Sci. 7 (1):55 - 58, 2008.

7. Attia,Y.A., AbdEl- Rahman, S.A. and Qota, E. M. A., Effects of microbial phytase without out on with cell-wall splitting enzymes on the performance of broilers fed marginal levels of dietary protein and metabolizable energy. Egyptian Poultry Science. 21(11): 521-547, 2001.

8. Iyayi, E. A., Aderemi, F. A., Ladele, O. O., Popoola, A. S., Effects of low protein diets supplemented with amino acids (Methionine or lysine) on performance of broilers. American Journal of Experimental Agriculture 4(5): 525-531, 2014.

9. Furlan, R. L., Faria Filho, D. E., Rosa, P. S. and Macari, M., Does low-protein diet improve broiler performance under heat stress conditions? Brazilian Journal of Poultry Science. 6(2): 71-79, 2004.

10.Nasr, J. and Kheiri, F., Effects of lysine levels of diets formulated based on total or digestible amino acids on broiler carcass composition. Brazilian Journal of Poultry Science. 14(4): 233-304, 2012.

11.Rezaei, M., Moghaddam, H. N., Reza, J. P., and Kermanshahi, H., The Effects of Dietary Protein and Lysine Levels on Broiler Performance, Carcass Characteristics and $\mathrm{N}$ Excretion. Int. J. Poult. Sci. 3(2): 148-152, 2004.

12.Ojediran, T. K., Onaolapo, O. B., Obimakinde, B. S., Akpan, E. U. and Emiola, I. A. Response and Economic Indices of Broilers on Low Crude Protein Diets Fortified with Lysine. American Journal of Experimental Agriculture. 10(4): 1-7, 2015.

13. Corzo, A., Fritts, C. A., Kidd, M. T. and Kerr, B. J., Response of broiler chicks to essential and non-essential amino acid supplementation of low crude protein diets. Journal of Animal Feed Science Technology. 118: 319-327, 2005.

14.Church, D.C. and Varela-Alvarez, A., Ration Formulation. In: Livestock Feed and Feeding. 3rd Ed. D.C. Church, Ed. Prentice Hall. Englewood Cliffs, New Jersey. 1991

15.Sklan, D. and Plavnik, I. Interactions between dietary crude protein and essential samino acid intake on performance in broilers. British Journal of Poultry Science. 43(3): 442-449, 2002.

16.Perry, T.W., A.E. Cullison and Lowrey, R.S., Feeds and Feeding. 6th Ed. Pearson Education, Inc. Upper Saddle River, New Jersey. 2004 
17. Oluyemi. J. N. and Robert, F. A., Poultry production in warm wet climate. Macmillan publishers Ltd., London.Pp.142-160, 2000.

18. Oguntoyinbo, J. S., Vital statistics in Ogbomoso Community. Day Bis Ltd, Ibadan, Nigeria: Pp 2-6, 1978.

19. Mitruka, H. M, Rawnsley, S. K. S., Chemical, biochemical and haematological, reference in normal experimental animals. Mason, N.Y. Pp. 287-380, 1977.

20.Schalm, O. W., Jane, N. C., Carol, E. J., Veterinary haematology. $3^{\text {rd }}$, Edition. Lea and Febiger Philadelphia. 1975.

21.Roschlan, P., Bernet, E. and Gruber, W.. Enzymatische best immugoles gesamt cholesterius in serum. Journal of clinical chemistry and Biochemistry, 12: 403-407, 1974.

22.Friedewald, W. T., Levy, R. I. and Fredrickson, D. S., Estimation of the concentration of low-density lipoprotein cholesterol in plasma without use of the preparative ultra centrifuge. Clinical chemistry, 18 (6):499-502, 1972.

23.Schmidt, E. and Schmidt FW. Determination of serum glutamic oxaloacetic and glutamic pyruvic transaminase. Biological Clinics.3:1, 1963.

24.Peters, T., Biomont, C.T. and Doumas, B. T., Protein (total protein) in serum, urine and cerebrospinal fluid, albumin in serum: In selected methods of clinical chemistry, volume 9. W. R. Faulkner and S. Meites (eds.) Washington D.C. American Association of Clinical Chemist. 1982.

25.SAS Institute., SAS/ STAT Guide for personal computers version and Edition Cary North Carolina, SAS Insitute; 2000.

26.Malik, S., Kumar, A., Verma, A. K., Gupta, M. K., Sharma, S. D., Sharma, A. K. and Rahal, A., Haematological profile and blood chemistry in diarrhoeic calves affected with collibacillosis. J. Anim. Health Prod. 1(1): 10 - 14, 2013.

27.Adeyemi, O. A., Fashina, O. E. and Balogun, M. O., Utilization of Full-Fat Jatropha Seed in Broiler Diet: Effect on Haematological Parameters and Blood Chemistry. Proc. 25th Annual Conference Nig Soc Anim. Prod (NSAP). Pp 108 - 109, 2000 .
OJEDIRAN T. K., et al.

28.Sahir, M. H., Shariatmadari, F., Mirhadi, S. A. and Chwalibog, A., The effect of lysine supplements on haematology on haematology and serum biochemical indices of broiler breeders. Arch. Geflugelk. 70(2): 74-80, 2006.

29.Faluyi, O. B., Agbede, J. O. and Adebayo, A., Growth performance and immunological response to newcastle disease, vaccinations of broiler chickens fed lysine supplemented diets. J. Vet. Med. 7(3): 77-84, 2015.

30.Nse Abasi N. E., Akpabio, U., Okpongete, R. O. and Edem, E. A., Do Diet Affect Haematological Parameters of Poultry? British Journal of Applied Science \& Technology. 4(13): 1952-1965, 2014.

31.Suchint, S., Orawan, C. and Worapol, A., Haematological, electrolyte and serum biochemical values of the Thai Indigeneous Chickens (Gallus domesticus) in Northeastern Thailand. Sangklanakanin J. Sci. Technol. 26(3): 425-437, 2004

32.Bolu, S. A and Balogun, O. O., Comparative performance and carcass evaluation of broilers fed locally produced natural vitamin premix and commercial vitamin/premixes. Nigerian Journal of Pure and applied Science. 5:1110-1113, 2000.

33.Atteh, J. O., Theory and Practice of poultry production: Adlek Printer Ilorin, Nigeria. Pp 65, 2004.

34.Ani, A. O., Ogbu, C. C., Abakasanga, I. U. and Ugwuowo, L. C. Response of Broiler Birds to Varying Dietary Levels of Gongronema Latifolium Leaf Meal. Journal of Biology, Agriculture and Healthcare. 3(14): 67-74, 2013.

35.Rezaei, M., Moghaddam, H. N., Reza, J. P. and Kermanshahi, H., The Effects of Dietary Protein and Lysine Levels on Broiler Performance, Carcass Characteristics and $\mathrm{N}$ Excretion. International Journal of Poultry Science 3(2): 148-152, 2004.

36.Mohamed, M. A., El-Daly, E. F., Abd ElAzeem, N. A., Youssef, A. W. and Hassan, H. M. A., Growth performance and histological changes in ileum and immune related organs of broilers fed organic acids or antibiotic growth promoter. International Journal of Poultry Science 13 (10): 602610, 2014. 